\title{
Genus Bourrellyodesmus (Desmidiaceae, Zygnemaphyceae) in the state of São Paulo, Brazil ${ }^{1}$
}

\author{
SÍLVIA M.M. FAUSTINO² and CARLOS E.M. BICUDO ${ }^{3,4}$
}

(received: November 27, 2003; accepted: July 22, 2004)

\begin{abstract}
Genus Bourrellyodesmus (Desmidiaceae, Zygnemaphyceae) in the state of São Paulo, Brazil). Floristic survey of genus Bourrellyodesmus (Desmidiaceae, Zygnemaphyceae) was based on 149 sample units, 76 of which were already deposited at the Herbário Científico do Estado "Maria Eneyda P. Kauffmann Fidalgo" (SP) of the Instituto de Botânica, Secretaria do Meio Ambiente do Estado de São Paulo, and 73 of which were collected during 2000-2001. Two species of Bourrellyodesmus were identified: B. jolyanus (C. Bicudo \& Azevedo) C. Bicudo \& Compère e B. guarrerae sp. nov.
\end{abstract}

Key words - Algae, biodiversity, Brazil, floristic survey, taxonomy

RESUMO - (O gênero Bourrellyodesmus (Desmidiaceae, Zygnemaphyceae) no estado de São Paulo, Brasil). O levantamento florístico do gênero Bourrellyodesmus (Desmidiaceae, Zygnemaphyceae) foi baseado em 149 unidades amostrais, 76 das quais já se encontravam depositadas no Herbário Científico do Estado "Maria Eneyda P. Kauffmann Fidalgo" (SP) do Instituto de Botânica, Secretaria do Meio Ambiente do Estado de São Paulo e 73 foram coletadas no período 2000-2001. Duas espécies de Bourrellyodesmus foram identificadas: B. jolyanus (C. Bicudo \& Azevedo) C. Bicudo \& Compère e B. guarrerae sp. nov.

Palavras-chave - Algas, biodiversidade, Brasil, levantamento florístico, taxonomia

\section{Introduction}

Genus Bourrellyodesmus was proposed by Compère (1976) and presently includes five species. First report of occurrence of representatives of this genus in Brazil is in Bicudo \& Azevedo (1977). The material studied was gathered by $\mathrm{C}$. Bicudo and Laine Sormus from a shallow swampy area with a grasscovered bottom, located near the church of Our Lady Aparecida, in the municipality of Aparecida, state of São Paulo, southeastern Brazil. This material was the basis for the description and proposal of a new Arthrodesmus species, A. jolyanus C. Bicudo \& Azevedo that would later on be transferred to Bourrellyodesmus, under the combination B. jolyanus (C. Bicudo \& Azevedo) C. Bicudo \& Compère (Bicudo \& Compère, 1978).

The two papers above constitute all the knowledge of the genus Bourrellyodesmus for the state of São Paulo.

Geographical area covered by the two above papers is minimal, since they refer to just one locality in the state of São Paulo. Present paper is pioneer in the

1. Parte da dissertação de mestrado de S.M.M. Faustino.

2. Doutoranda, Universidade de São Paulo, "campus" de Ribeirão Preto, SP, Brasil. (fitomathes@yahoo.com.br)

3. Instituto de Botânica, Seção de Ecologia, Caixa Postal 4005, 01061-970 São Paulo, SP, Brasil.

4. Corresponding author: cbicudo@terra.com.br sense that it presents a broad survey of the genus for São Paulo State, with uniform collecting techniques, thus considerably broadening the geographical area covered and the taxonomical knowledge of the genus in the area mentioned. Present research is part of the BIOTA/FAPESP project entitled "Algalflora of the state of São Paulo".

\section{Material and methods}

The study area is that of the state of São Paulo (figure 1). Description of taxa and synonyms presently considered specifically refer to the state of São Paulo.

One hundred and forty nine sample units were studied, collected from 111 localities in the state of São Paulo. The only three samples in which occurred specimens of Bourrellyodesmus are listed below according to their increasing access to the herbarium code numbers:

1. BRASIL: São PAULO: Aparecida do Norte, old road from Aparecida do Norte to Pindamonhangaba, swampy area, $500 \mathrm{~m}$ from the Nossa Senhora Aparecida Sanctuary, periphyton, 18-II-1972, C.E.M. Bicudo \& L. Sormus s.n. (SP104843).

2. BRASIL: SÃo PAULO: Rifaina, bridge over the river Grande that limits municipalities of Rifaina and Araxá, phytoplankton, $20^{\circ} 04^{\prime} 24.8^{\prime \prime}$ S, $47^{\circ} 25^{\prime} 02.5$ ” W, 30-V-2000, C.E.M. Bicudo \& D.C. Bicudo s.n. (SP336342).

3. BRASIL: SÃo PaUlo: Novo Horizonte, SP-304, km 451, swamp, periphyton collected with plankton net, 2126'51.4" S, 49¹0'08.6”' W, 14-II-2001, C.E.M. Bicudo et al. s.n. (SP336349). 


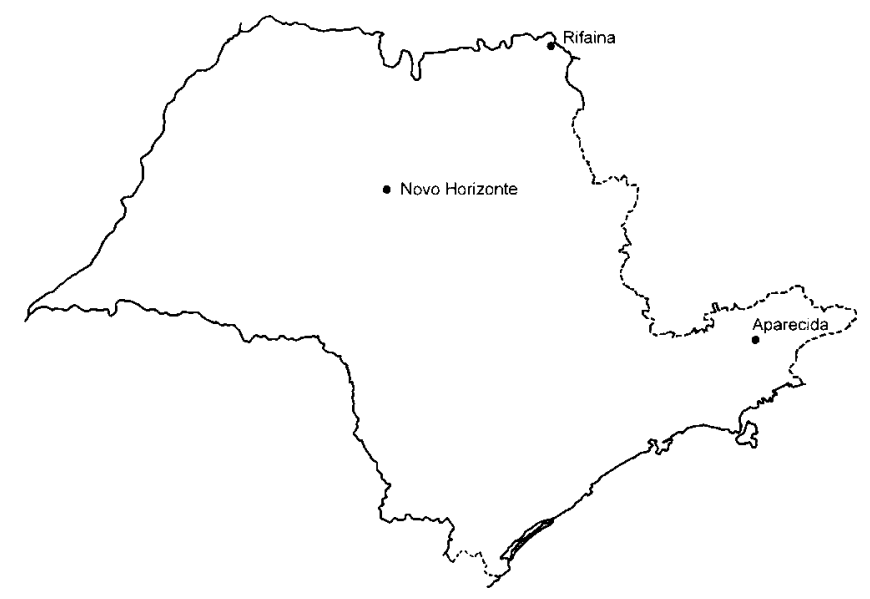

Figure 1. Map of the state of São Paulo showing municipalities in which Bourrellyodesmus specimens were collected.

Collections were performed in either lentic or lotic environments, and both planktonic and periphytic materials were collected. Sampling of plankton material was performed by using one $20 \mu \mathrm{m}$ nylon plankton net. Net was used as many times in the system's superficial layer ( $\pm 30 \mathrm{~cm}$ depth), as was needed to obtain a reasonable amount of material. Measure of such a 'reasonable amount' was taken by the naked eye according to the appearance of a greenish to greenish-brown mass that accumulated at the bottom of the collecting vial. Such a slimy mass is, in general, very rich in desmid material. Samplings were carried out in the littoral zone of both lotic and lentic systems, where there are usually plenty of attached aquatic plants, floating or totally or partially submersed, making such environments natural plankton traps. Periphytic material was collected by manual squeezing of totally or partially submersed plants (bryophytes, pteridophytes, and phanerogams), and by gathering entire specimens or submersed parts of emergent specimens. Pebbles were collected or, depending on their size, scraped and the scrapings collected in a vial.

Sample fixation and preservation was performed immediately after collection, in the field, with formaldehyde $3 \%-5 \%$ aqueous solution. Immediate fixation aimed at preserving cell morphology as much as possible to that at the moment of collection. Concentration of material in the vial may cause acceleration of the cell division rate in certain species, specially in those of desmids and, consequently, production of many abnormal phenotypes because the alga has not enough time to fully develop all its structures before undergoing a new division. Since apparent morphology is the basis for the sorting out of species in Bourrellyodesmus, it is mandatory that such results of malformations be avoided and, if they occur, that they are not mistaken for regular expressions of the intra-population morphological variation spectrum.

All material studied is deposited at the Instituto de Botânca herbarium (SP). All information pertaining to the sampling localities include geographical coordinates taken with GPS.

\section{Results and Discussion}

Bourrellyodesmus Compère, Rev. Algol., nouv. sér. 11:340. 1976.

Cells isolated, deeply constricted at the median region, isthmus narrow, sinus linear or acute-angled; semicells elliptic to sub-rectangular, with 1 spine located on each side at the median or the lowest one third portion of the semicell, in the latter case immediately above the isthmus, center of semicell with 1 tubercle or several conspicuous granules, each granule surrounded by 6 triangular scrobiculations; cell margin smooth; cell vertical view elliptic or elliptic-fusiform (2-radiate); chloroplast 1 per semicell, with 1 (monocentric) or 2 (dicentric) pyrenoids; some larger specimens of the genus may have 2 chloroplasts.

Type-species: B. heimii (Bourrelly) Compère, Rev. Algol., nouv. sér., 11:340, fig. 1. 1976.

Genus Bourrellyodesmus was proposed by Compère (1976) to include A. heimii Bourrelly, a species then classified in the section Ornatae Bourrelly ex C. Bicudo \& Azevedo of genus Arthrodesmus. Section Ornatae was originally proposed by Bourrelly (1966) to include all individual specimens having two spines located one on each side of semicells, at the same level in each semicell, and cell wall with a median facial decoration composed of just one granule or wart (emarginated granule) or several granules surrounded by triangular scrobiculations.

At present, the following five species are included in this genus: Bourrellyodesmus heimii (Bourrelly) Compère, B. jolyanus (C. Bicudo \& Azevedo) C. Bicudo \& Compère, B. sumatranus C. Bicudo \& Compère, B. excrescens (Scott \& Grönblad) C. Bicudo \& Compère, and B. spechtii (Scott \& Prescott) C. Bicudo \& Compère.

Artificial key for identification of species studied

1. Cell wall with 1 facial median granule and 2 intramarginal ones; cell $23.0-27.0 \times 21.0-24.0 \mu \mathrm{m} . . .$. B. jolyanus

1. Cell wall with 1 facial median granule, no intramarginal ones; cell 7.0-9.2 ×6.9-10.0 $\mu \mathrm{m}$

B. guarrerae 
Bourrellyodesmus jolyanus (C. Bicudo \& Azevedo) C. Bicudo \& Compère, Bull. Jard. bot. nat. Belg. 48(3-4):416, fig. 9. 1978.

Figure 2

Basionym: Arthrodesmus jolyanus C. Bicudo \& Azevedo, Biblthca phycol. 36:64, fig. 73. 1977.

Cells as long as broad without spines, deeply constricted at the median portion; semicells elliptic to sub-elliptic in front view, dorsal margin slightly convex at the middle, suddenly arcuate after the granules, 2 granules visible on each side at the point in which there is an abrupt change in the degree of curvature of the dorsal margin, basal margin convex, somewhat arcuate, angles with 1 short, solid, straight, acute spine, sinus open, acute-angled; cell wall hyaline, smooth, 1 median facial swelling just above the isthmus; semicell vertical view nearly oblong, sides parallel or almost so, angles truncate rounded, 1 short spine, 2 intramarginal granules on each side, near the spines, 1 median swelling; chloroplasts and pyrenoid not observed. Measurements: cell length $23.0-27.0 \mu \mathrm{m}$, breadth (including spines) 30.0-33.0 $\mu \mathrm{m}$, (without spines) 21.0-24.0 $\mu \mathrm{m}$, thickness 16.0-17.5 $\mu \mathrm{m}$, breadth of isthmus ca. $10.0 \mu \mathrm{m}$.

In literature: Municipality of Aparecida (Bicudo \& Azevedo, 1977:64, as Arthrodesmus jolyanus C. Bicudo \& Azevedo).

Specimens examined: BRASIL: São PaUlo: Aparecida do Norte, old road from Aparecida do Norte to Pindamonhangaba, swampy area, $500 \mathrm{~m}$ from the Nossa Senhora Aparecida Sanctuary, periphyton, 18-II-1972, C.E.M. Bicudo \& L. Sormus s.n. (SP104843).

Bourrellyodesmus jolyanus is easily identified by having nearly elliptic semicells in front view, one short spine at each angle, and five granules visible in front view, two of which are located immediately below the dorsal margin of the semicells, on each side, at the point in which there is an abrupt change in the degree of curvature of the already mentioned margin, and another one, a little bigger than the two preceding ones located about in the center of the face of each semicell.

The shape of the semicells of B. jolyanus (C. Bicudo \& Azevedo) C. Bicudo \& Compère resembles that of Xanthidium concinnum Archer var. floridense Scott \& Grönblad (Scott \& Grönblad, 1957:30, pl. 17, fig. 11). However, there are some marked differences regarding the dorsal margin of the semicells that is slightly convex in the first and straight in the latter, the pattern of distribution of the upper angles decoration that is represented by two pairs of granules on each pole of the first and one pair of short acute spines in the latter, and the shape of the semicells in vertical view that is somewhat oblong in the first and elliptic-oblong in the other. There is also some difference in the cell dimensions, since the size of individual cells of B. jolyanus (C. Bicudo \& Azevedo) C. Bicudo \& Compère is slightly more than twice that of $X$. concinnum Archer var. floridense Scott \& Grönblad.

Bourrellyodesmus guarrerae Faustino \& C. Bicudo, sp. nov.

Figures 3-4

Cellulae paullum latae quam longae, raro longiores quam latae sine spinis, in media parte valde profundae et constrictae; semicellulae ellipticae quase circulares, margo superior convexa in parte media et basalis margo

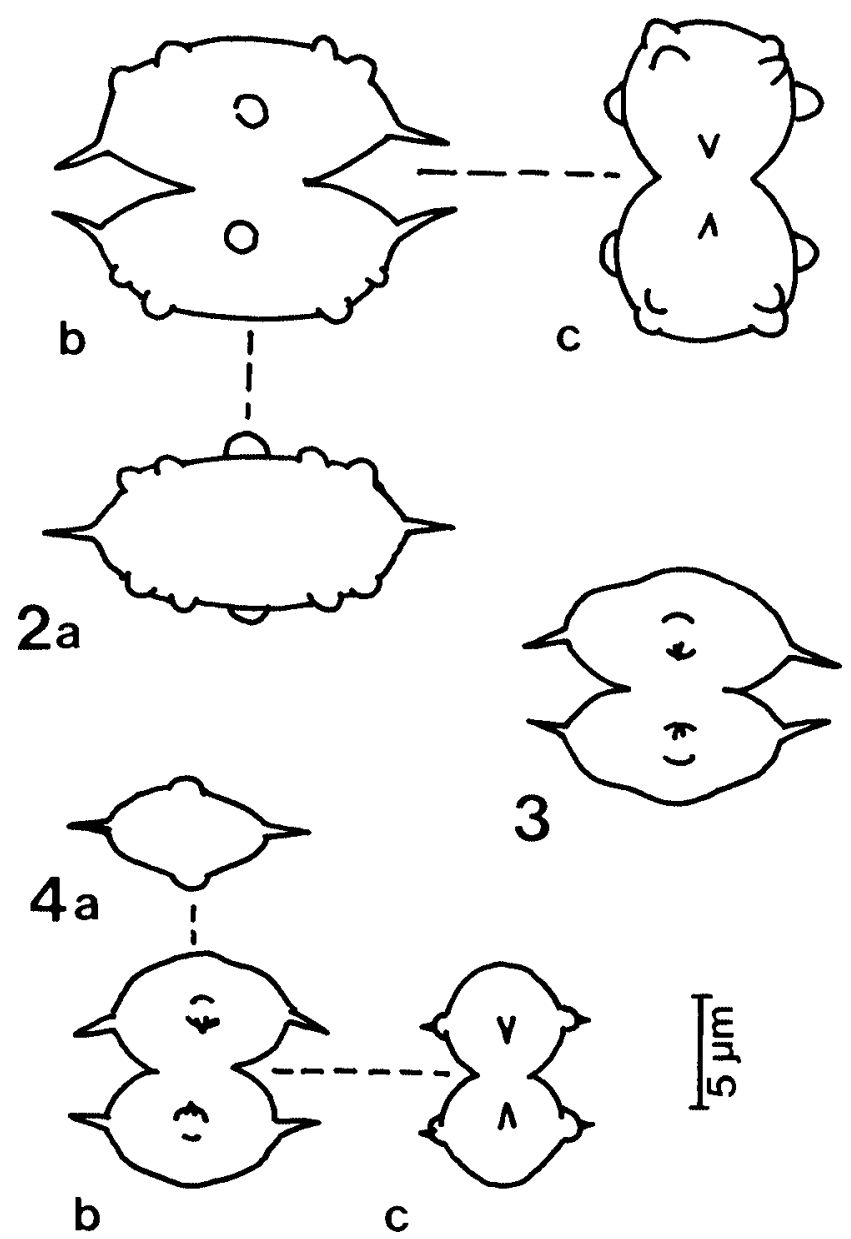

Figure 2-4. 2. Line drawings of Bourrellyodesmus jolyanus (C. Bicudo \& Azevedo) C. Bicudo \& Compère. 2a. Vertical view. 2b. Front view. 2c. Lateral view. Figures 3-4. Line drawings of Bourrellyodesmus guarrerae Faustino \& C. Bicudo, sp. nov. (SP336342). 4a. Vertical view. 4b. Front view. 4c. Lateral view. 
convexa plus minusve arcuata; anguli ornati sunt 1 solido spino, recto, curto, acuto; sinus medianus apertus, acutangularis; paries cellularis hyalina, glabra, 1 faciale granulo in semicellula plus minusve centraliter posito; semicellula a vertice visa valde elliptica usque ad ellipticam-fusiformam, utrinque latus 1 spino curto, 1 granulo meridiano marginale; chloroplastidia et pyrenoidia non observata. Cellulae: longitudine 7,0-10,2 $\mu \mathrm{m}$, latitudine (cum spinis) 9,1-13,0 $\mu \mathrm{m}$, (sine spinis) $6,9-10,0 \mu \mathrm{m}$; crassitudine 4,0-5,0 $\mu \mathrm{m}$, latitudine isthmi 3,9-5,5 $\mu \mathrm{m}$.

Holotypus: figurae nostrae e fluminis Grande, juxta lateris sinistri pontem, Municipium Rifaina, Provincia Sanctus Paulus, 30-V-2000, C.E.M. Bicudo \& D.C. Bicudo (SP336342) illustratae.

Cells about as long as broad without spines, 1.3-1.4 times broader than long with spines, deeply constricted at the middle; semicells elliptic to almost circular in front view, dorsal margin convex at the middle, basal margin convex, somewhat arcuate, angles furnished with 1 short, solid, straight, acute spine, sinus open, acute-angled; cell wall hyaline, smooth, 1 facial granule located approximately at the center of semicells; semicell apical view broadly elliptic to elliptic-fusiform, 1 short spine on each side, 1 marginal, median granule; chloroplasts and pyrenoid not observed. Measurements: cell length 7.0-10.2 $\mu \mathrm{m}$, breadth (including spines) 9.1-13.0 $\mu \mathrm{m}$, (without spines) 6.9-10.0 $\mu \mathrm{m}$, thickness 4.0-5.0 $\mu \mathrm{m}$, breadth of isthmus 3.9-5.5 $\mu \mathrm{m}$.

In literature: first report.

Specimens examined: BRAZIL: São PAULO: Rifaina, bridge over the river Grande that limits municipalities of Rifaina and Araxá, phytoplankton, 20 04'24.8" S, $4^{\circ} 25^{\prime} 02.5^{\prime}$ W, 30-V-2000, C.E.M. Bicudo \& D.C. Bicudo s.n. (SP336342); Novo Horizonte, SP-304, $\mathrm{km} 451$, swamp, periphyton collected with plankton net, 2126'51.4" S, 49¹0'08.6” W, 14-II-2001, C.E.M. Bicudo et al. s.n. (SP336349).

The comprehensive taxonomical study of the genus Bourrellyodesmus by Bicudo \& Compère (1978) provided combinations for every species of section Ornatae Bourrelly ex C. Bicudo \& Azevedo of genus Arthrodesmus Ehrenberg ex Ralfs that fit in the new genus' circumscription.

Present specimens from municipalities of Rifaina and Novo Horizonte, in the state of São Paulo, are extremely characteristic by being slightly broader than long (figure 3), seldom longer than broad (figure 4), if the spines are disregarded and deeply constricted at the median portion. Semicells vary from elliptic (figure 3) to almost circular (figure 4), with dorsal margin more or less broadly convex at the middle and basal margins also convex, in such a way that the first one and the latter two taken together are almost equally convex. Lateral angles are furnished with a short, solid, straight, acute spine. Sinus is open, acute-angled. The cell wall is hyaline, smooth, and has one granule located about in the center of the face of each semicell. In vertical view, the cell is broadly elliptic to elliptic-fusiform, with a short, acute spine on each pole and a median marginal granule. Despite present examination of several individual cells, chloroplasts and pyrenoid were never observed.

Bourrellyodesmus guarrerae morphologically resembles $B$. jolyanus (C. Bicudo \& Azevedo) C. Bicudo \& Compère, from which it is distinct by the lack of intramarginal granules and in the much smaller cell size (B. guarrerae: 7.0-10.2 × 6.9-10.0 $\mu \mathrm{m}$; B. jolyanus: $23.0-27.0 \times 21.0-24.0 \mu \mathrm{m})$.

The species is named after Prof. Dr. Sebastián Alberto Guarrera, from the Universidad Nacional de La Plata, Argentina, one of the cornerstones for the development of phycology in that country.

Acknowledgements - Authors are indebted to Dom Diógenes Silva Matthes for preparation of the Latin diagnosis, and to the Fundação de Amparo à Pesquisa do Estado de São Paulo, for partial financial support represented by grants 98/04955-3 given to CEMB and 99/07388-5 given to SMMF.

\section{References}

BICUDO, C.E.M. \& AZEVEDO, M.T.P. 1977. Desmidioflórula paulista, 1: gênero Arthrodesmus Ehr. ex Ralfs emend. Arch. Bibliotheca Phycologica 36:1-105.

BICUDO, C.E.M. \& COMPÈRE, P. 1978. A taxonomic study of the desmid genus Bourrellyodesmus (Zygnemaphyceae). Bulletin du Jardin Botanique National de Belgique 48:409-426.

BOURRELLY, P.C. 1966. Les algues d'eau douce: initiation à la systématique: les algues vertes. Éditions N. Boubée \& Cie., Paris, v.1.

COMPÈRE, P. 1976. Bourrellyodesmus, nouveau genre de Desmidiacées. Revue Algologique, nouvelle série, 11:339-342.

SCOTT, A.M. \& GRÖNBLAD, R. 1957. New and interesting desmids from the Southeastern United States. Acta Societatis Scientiarum Fennicae, series B, 2:1-62. 